\title{
Detection of Escherichia coli 0157:H7 in soil and water using multiplex PCR
}

\author{
G.R. Campbell ${ }^{1}$, J. Prosser ${ }^{2}$, A. Glover ${ }^{2}$ and K. Killham ${ }^{1}$ \\ ${ }^{1}$ Department of Plant and Soil Science, University of Aberdeen and ${ }^{2}$ Department of Molecular and Cell Biology, \\ Institute of Medical Sciences, University of Aberdeen, Aberdeen, Scotland, UK
}

53/4/01: received 9 April 2001, revised 22 May 2001 and accepted 31 May 2001

G.R. CAMPBELL, J. PROSSER, A. GLOVER AND K. KILLHAM. 2001.

Aims: To evaluate the suitability of a multiplex PCR-based assay for sensitive and rapid detection of Escherichia coli $\mathrm{O} 157: \mathrm{H} 7$ in soil and water.

Methods and Results: Soil and water samples were spiked with E. coli $\mathrm{O} 157: \mathrm{H} 7$ and subjected to two stages of enrichment prior to multiplex PCR. Detection sensitivities were as high as $1 \mathrm{cfu} \mathrm{ml}^{-1}$ drinking water and $2 \mathrm{cfu} \mathrm{g}^{-1}$ soil. Starvation of E. coli $\mathrm{O} 157: \mathrm{H} 7$ for $35 \mathrm{~d}$ prior to addition to soil did not affect the ability of the assay to detect initial cell numbers as low as $10 \mathrm{cfu} \mathrm{g}^{-1}$ soil. Use of an 8-h primary enrichment enabled detection of as few as $6 \mathrm{cfu} \mathrm{g}^{-1}$ soil, and $10^{4} \mathrm{cfu} \mathrm{g}^{-1}$ soil with a 6 -h primary enrichment. When soil was inoculated with $10^{5} \mathrm{cfu} \mathrm{g}^{-1}$, the PCR assay indicated persistence of $E$. coli $\mathrm{O} 157: \mathrm{H} 7$ during a $35 \mathrm{~d}$ incubation. However, when soil was inoculated with lower numbers of pathogen, PCR amplification signals indicated survival to be dependent on cell concentration.

Conclusions: A multiplex PCR-based assay, in combination with an enrichment strategy enabled sensitive and rapid detection of E. coli $\mathrm{O} 157: \mathrm{H} 7$ in soil and water.

Significance and Impact of the Study: The ability to sensitively detect E.coli O157:H7 in environmental material within one working day represents a considerable advancement over alternative more time-consuming methods for detection of this pathogen.

\section{INTRODUCTION}

In humans, production of one or more related toxins, the Shiga-like toxins, by Escherichia coli $\mathrm{O} 157: \mathrm{H} 7$, may lead to haemorrhagic colitis and, in severe cases, haemolyticuraemic syndrome and thrombotic thrombo-cytopaenic purpura (Jones 1999). Ingestion of as few as 10 organisms may be sufficient to cause infection (Willshaw et al. 1994). A recent study showed that prevalence of $E$. coli $\mathrm{O} 157: \mathrm{H} 7$ within the UK cattle herd may be as high as $15.7 \%$ (Chapman et al. 1997). Escherichia coli O157:H7 is readily shed by cattle at rates ranging from $10^{2}$ to $10^{5} \mathrm{cfu} \mathrm{g}^{-1}$ (Zhao et al. 1995), making cattle faeces an important source of this pathogen in the environment and contact with contaminated faeces a risk to humans (Chapman 2000). Agricultural waste, which includes livestock slurries and manure, represents approximately $96 \%$ of total organic waste applied to land in

Correspondence to: K. Killham, Department of Plant and Soil Science, University of Aberdeen, Cruickshank Building, Aberdeen, AB24 3UU, UK (e-mail:k.killham@abdn.ac.uk).
Scotland, which has been estimated to equate to an input of 15 million tonnes annually (Scottish Environment Protection Agency 1998). Thus, as well as direct animal input of contaminated faeces to soil, the current practice of agricultural waste disposal to land also represents a potential environmental hazard regarding prevalence of $E$. coli O157:H7.

There have been few systematic studies of survival of $E$. coli O157:H7 in the environment, particularly the terrestrial environment. Limited observations, however, suggest considerable survival periods in cattle faeces, silage, soil and municipal water (Wang and Doyle 1998; Fukushima et al. 1999; Maule 1999; Fenlon and Wilson 2000; Fenlon et al. 2000; Mubiru et al. 2000). The vertical transmission of E. coli O157:H7 from contaminated cattle faeces through soil has also been demonstrated, indicating risk of contamination of private drinking water supplies (Gagliardi and Karns 2000).

The possibility of prolonged survival of $E$. coli $\mathrm{O} 157: \mathrm{H} 7$ in the environment, linked to the intensive agricultural production systems being practiced in UK agriculture, pose potential risks of contamination to food crops and rural 
drinking water. In order to minimize risks of infection to producer and consumer, sensitive and rapid means of $E$. coli O157:H7 detection are required. To obtain sufficient sensitivity of $E$. coli $\mathrm{O} 157: \mathrm{H} 7$ detection, traditional methods have relied upon a preliminary enrichment step followed by plating on selective media, such as Sorbitol MacConkey agar (SMAC) and screening negative sorbitol-fermenting colonies using latex antibody agglutination assays (Taormina et al. 1998). Selectivity for the O157:H7 serotype has been improved using selective additions to SMAC agar including rhamnose, cefixime and potassium tellurite (Chapman et al. 1991; Zadik et al. 1993). Additional methods, such as the introduction of immunomagnetic separation (IMS) during enrichment, have improved sensitivity and selectivity of detection assays (Wright et al. 1994). A major limitation of these methods, however, is the time required for positive identification of the O157:H7 serotype. Further characterization of the potential of isolates to produce Shiga-like toxin also adds to the time and expense of culture-based assays.

Recent evidence suggests that antibody-based approaches, such as IMS, may result in false negative detection of E. coli O157:H7 due to loss of surface antigen properties induced by starvation (Hara-Kudo et al. 2000). This may be particularly likely in the environment where starvation conditions will prevail. In contrast to antibody-based methods, PCR-based detection tends to be more rapid and can eliminate many of the problems associated with culturebased methods. By targeting nucleic acid, PCR approaches avoid the problems of relying on expression of unique phenotypes associated with the E. coli O157:H7 serotype. Numerous PCR-based assays for E. coli O157:H7 are reported in the literature (e.g. Meng et al. 1997; Nagano et al. 1998; Oberst et al. 1998; Fratamico et al. 2000). A muliplex PCR approach, can further improve the specificity of a PCR assay to the O157:H7 serotype, overcoming a problem observed using only single gene target PCR formats (e.g. Hu et al. 1999; Fratamico et al. 2000). Information on important E. coli $\mathrm{O} 157: \mathrm{H} 7$ markers, such as the presence of $0157, \mathrm{H} 7$, intimin and Shiga-like toxin genes, can be obtained in one step (Hu et al. 1999). Thus PCR-based approaches offer the potential to be more rapid than other methods of E. coli $\mathrm{O} 157: \mathrm{H} 7$ detection. The overall aim of this study, therefore, was to assess the suitability of a multiplex PCR-based assay, previously designed by $\mathrm{Hu}$ et al. (1999), in combination with an enrichment step, for detection of E. coli $\mathrm{O} 157: \mathrm{H} 7$ in soil and water samples. Specific objectives were to investigate the detection sensitivity of this assay, assess the effects of cell starvation on detection sensitivity and determine the minimum enrichment time required for positive identification of the $\mathrm{O} 157: \mathrm{H} 7$ serotype. A final objective was to use the multiplex PCR assay to monitor change in pathogen populations introduced into soil.

\section{MATERIALS AND METHODS}

\section{Bacterial strain}

Escherichia coli $\mathrm{O} 157: \mathrm{H} 7$ strain 3704 was used throughout this study. Strain 3704 is a nontoxigenic environmental isolate obtained from the E. coli Reference Laboratory, Aberdeen. The strain was originally isolated from a farm drain and has been proven to be nontoxigenic due to the absence of toxin activity (by Verocell assay) and toxin genes (by PCR) (F. Thomson-Carter, unpublished observation).

\section{Environmental samples}

All samples were collected in June 2000. Two Scottish soils, Cruden Bay (clay loam) and Glencorse (clay loam) were used in this study. Soils were sampled from 0 to $25 \mathrm{~cm}$ depth and homogenized by passage through a $3.35-\mathrm{mm}$ sieve. Samples of river water were obtained from the Rivers Dee and Don in Aberdeen. Private drinking water was obtained from a 10-m deep well on pasture grassland in rural Aberdeenshire. Prior to use, all samples were stored at $4^{\circ} \mathrm{C}$. Unless otherwise stated, all soil data are presented on a dry weight basis.

\section{PCR detection sensitivity in different environmental matrices}

A 15-h stationary phase culture of E. coli $\mathrm{O} 157: \mathrm{H} 7$ strain 3704 was serially diluted in sterile, quarter-strength Ringer's solution (Fisher Scientific UK Ltd). Dilutions were plated on Luria Bertani (LB) agar and incubated at $37^{\circ} \mathrm{C}$ for $18 \mathrm{~h}$ and cell numbers calculated from the mean number of colony forming units (cfu) obtained from triplicate plates at the appropriate dilution. Soil $(10 \mathrm{~g}$ fresh weight) or water $(10 \mathrm{ml})$ was then inoculated with $0.8 \mathrm{ml}$ aliquots of this dilution series. To ensure even distribution of added cells, soil and inocula were thoroughly mixed using a sterile spatula and water samples mixed by gentle, end over end inversion. After mixing, $1 \mathrm{~g}$ soil (fresh weight) or $1 \mathrm{ml}$ of water was added to sterile 50 -ml plastic incubation tubes (Greiner Labortechnik Ltd, Stonehouse, UK) containing $20 \mathrm{ml}$ of Tryptone Soya Broth (TSB) (Oxoid Ltd, Basingstoke, UK). Inoculated tubes were incubated at $37^{\circ} \mathrm{C}$ with continuous shaking $\left(200 \mathrm{rev} \mathrm{min}^{-1}\right.$ ) in an orbital shaker (Stuart Scientific, Redhill, UK) for $15 \mathrm{~h}$. Following incubation, $2 \mathrm{ml}$ of primary enrichment was added to $20 \mathrm{ml}$ of TSB and incubated for $6 \mathrm{~h}$ under the conditions described. Secondary enrichment cultures were then centrifuged at $10000 \mathrm{~g}$ for $15 \mathrm{~min}$. After centrifugation, supernatants were discarded and cell pellets were frozen at $-20^{\circ} \mathrm{C}$ prior to molecular analysis. 


\section{Preparation of DNA template and PCR analysis}

Cell pellets were suspended in $5 \mathrm{ml}$ of quarter-strength Ringer's solution and briefly vortexed. A 1-ml sample of cells was then transferred to a sterile Eppendorf tube and centrifuged at $15700 \mathrm{~g}$ for $10 \mathrm{~min}$. Following centrifugation, cell pellets were re-suspended in $1 \mathrm{ml}$ sterile distilled $\mathrm{H}_{2} \mathrm{O}$ and boiled for $20 \mathrm{~min}$. After boiling, lysed cell debris was removed by centrifugation ( $15700 \mathrm{~g}, 10 \mathrm{~min})$ and DNA in supernatant transferred to a fresh Eppendorf tube.

Multiplex PCR was performed on extracted DNA using primers targeting genes associated with $\mathrm{O} 157, \mathrm{H} 7$, intimin, Shiga-like toxin I and Shiga-like toxin II of E. coli O157:H7. The amplification primers, PCR cycling conditions and agarose gel electrophoresis visualization of PCR products were as described by $\mathrm{Hu}$ et al. (1999), with the exception that $1.5 \mu \mathrm{l}$ of template DNA (corresponding to approximately $10 \mathrm{ng}$ PCR reaction ${ }^{-1}$ ) was used as the PCR template throughout the study.

\section{Effects of cell starvation on PCR detection sensitivity}

A 20-ml volume of $15 \mathrm{~h}$ stationary phase $E$. coli $\mathrm{O} 157: \mathrm{H} 7$ culture was centrifuged at $10000 \mathrm{~g}$ for $10 \mathrm{~min}$. After discarding supernatant, cell pellets were washed twice with sterile quarter-strength Ringer's solution and finally re-suspended in $20 \mathrm{ml}$ of quarter-strength Ringer's solution. Aliquots of re-suspended cells $(1 \mathrm{ml})$ were then dispensed into Eppendorf tubes, placed in a $25^{\circ} \mathrm{C}$ incubator and starved for $0,1,3,7,14,21$ and $35 \mathrm{~d}$. Addition of cells to Glencorse soil, enrichment conditions and PCR analysis were as previously described.

\section{Minimum enrichment time and PCR detection sensitivity}

The effects of enrichment time on detection sensitivity of the PCR assay were investigated using DNA extracted at various time points from enrichment cultures of Glencorse soil spiked with different numbers of $E$. coli O157:H7. Only primary enrichment cultures were used in the PCR analysis. After incubation, under the conditions described previously, a $15-\mathrm{ml}$ volume of enrichment was centrifuged at $10000 \mathrm{~g}$ for $15 \mathrm{~min}$ to collect cells. DNA extraction and PCR analysis were as previously described.

\section{PCR detection of $E$. coli 0157:H7 population change in Glencorse soil}

Soil microcosms consisted of a plastic 20-ml Universal bottle containing $10 \mathrm{~g}$ (fresh weight) Glencorse soil. Soil microcosms were spiked with 10 -fold serial dilutions of $15 \mathrm{~h}$ stationary phase E. coli $\mathrm{O} 157: \mathrm{H} 7$ using the procedures described above and sealed with parafilm and incubated at $25^{\circ} \mathrm{C}$. Addition of inoculum to soil resulted in a moisture content of $52 \%$ of soil maximum water holding capacity, which was maintained throughout the experiment by measurement of microcosm mass and aseptic addition of sterile $\mathrm{dH}_{2} \mathrm{O}$ if required. Microcosms were sampled after $0,7,14,21$ and $35 \mathrm{~d}$ by removing $1 \mathrm{~g}$ (fresh weight) soil for analysis. Secondary enrichment and PCR analysis were as previously described.

\section{RESULTS AND DISCUSSION}

\section{Multiplex PCR detection sensitivity in different environmental matrices}

Multiplex PCR analysis of pure cultures of nontoxigenic E. coli $\mathrm{O} 157: \mathrm{H} 7$ strain 3704 revealed three distinct bands of expected size, corresponding to $\mathrm{H} 7$, intimin and $\mathrm{O} 157$ (Fig. 1). No PCR amplicons of the expected size were observed for Shiga-like toxin I and Shiga-like toxin II genes confirming previous data on the absence of toxin genes (by PCR) in this strain (F. Thomson-Carter, unpublished observation).

The sensitivity and robustness of the PCR-based assay were investigated by spiking different environmental samples with decreasing numbers of stationary phase $E$. coli O157:H7 and subjecting spiked material to a primary and secondary enrichment prior to DNA extraction and PCR amplification. The assay was extremely sensitive, capable of detecting initial E. coli $\mathrm{O} 157: \mathrm{H} 7$ populations $\leqslant 10 \mathrm{cfu} \mathrm{g}^{-1}$ or $\mathrm{ml}^{-1}$ in all of the environmental matrices tested (Table 1). Indeed, after enrichment, it was possible to detect $E$. coli O157:H7 populations as few as $1 \mathrm{cfu} \mathrm{ml}^{-1}$ in private drinking water. The assay was robust in contrasting soils, as soil properties such as humic content have been reported to inhibit PCR (Tebbe and Vahjen 1993). PCR amplification in the different soils used in this study, may therefore have arisen from dilution of PCR-inhibiting soil compounds in the secondary enrichment, while at the same time, enrichment served to increase numbers of the target bacteria.

\section{Effects of cell starvation on PCR detection sensitivity}

Throughout this study stationary phase cells of E. coli O157:H7 were added to soil. The ability to detect stationary phase starved populations of E. coli $\mathrm{O} 157: \mathrm{H} 7$ may be particularly important in environmental samples, where substrate concentrations are unlikely to favour growth. The limited data available suggest that E. coli O157:H7 can remain viable in soil and water for 


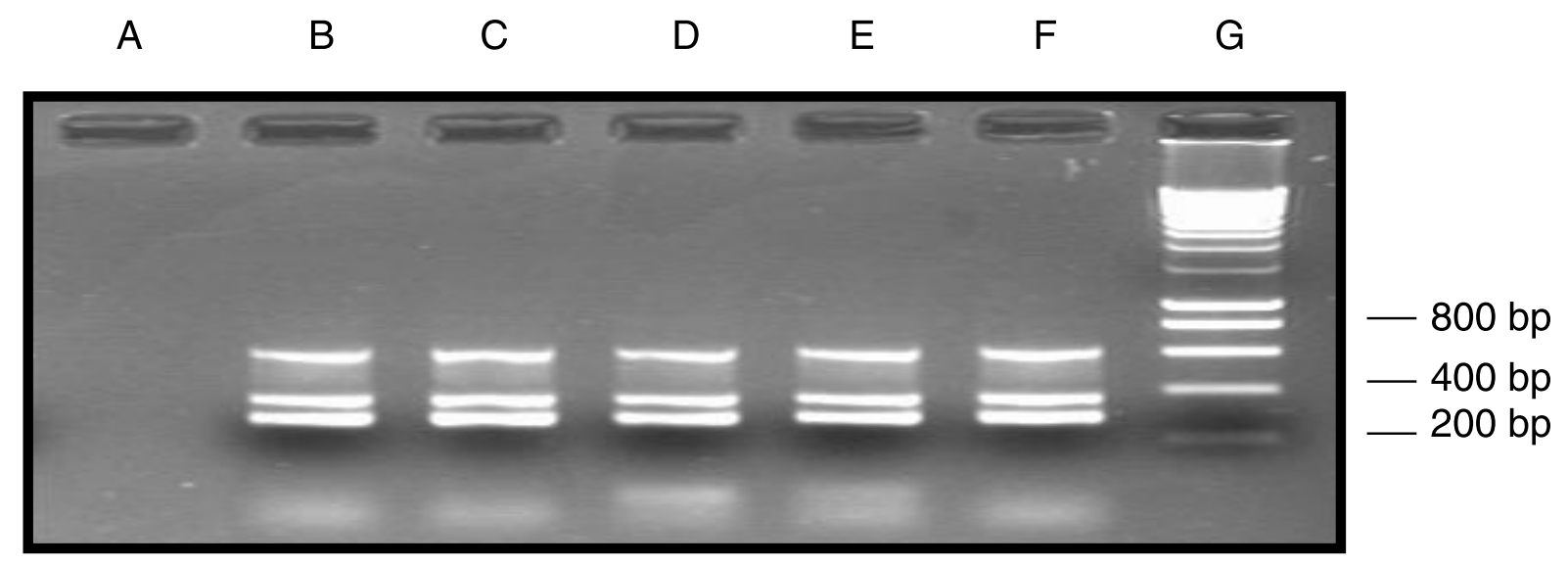

Fig. 1 Agarose gel electrophoresis of PCR amplified DNA from nontoxigenic Escherichia coli O157:H7 strain 3704 using H7, intimin and O157 PCR primers. H7 gene product (625 bp); intimin (368 bp) and O157 (292 bp). Lanes: (A) negative control (no template); (B-F) E. coli O157:H7 strain 3704; (G) HyperLadder (Bioline, UK, Ltd)

Table 1 PCR detection sensitivity for nontoxigenic Escherichia coli O157:H7 strain 3704 in a variety of different environmental matrices

\begin{tabular}{ll}
\hline Environmental material & PCR detection sensitivity \\
\hline Glencorse agricultural soil & $3 \mathrm{cfu} \mathrm{g}^{-1}$ oven dry soil \\
Cruden Bay agricultural soil & $10 \mathrm{cfu} \mathrm{g}^{-1}$ oven dry soil \\
River Don water & $8 \mathrm{cfu} \mathrm{m}^{-1}$ water \\
River Dee water & $6 \mathrm{cfu} \mathrm{m}^{-1}$ water \\
Private drinking water & $1 \mathrm{cfu} \mathrm{ml}^{-1}$ water \\
\hline
\end{tabular}

Numbers presented represent initial cfu added to sample.

considerable lengths of time (Wang and Doyle 1998; Fenlon et al. 2000; Mubiru et al. 2000). It is likely therefore that during survival in such environments, cells will encounter conditions of stress, such as nutrient starvation. This may alter the ability of E. coli $\mathrm{O} 157 \mathrm{H} 7$ to compete with indigenous microbial populations for nutrients during subsequent enrichment stages of detection, particularly when cell concentrations are low. This has been shown in studies in ground meat where stressing E. coli O157:H7 has been shown to reduce recovery of cells on nutrient agar (Rocelle et al. 1995). Experiments conducted in this study exposed cultures of E. coli $\mathrm{O} 157: \mathrm{H} 7$ to a range of periods of starvation in phosphate buffer, prior to soil inoculation. Starvation did not affect detection of low cell numbers in soil by the PCR assay (Table 2). Even after starvation for $35 \mathrm{~d}$, the assay was sufficiently sensitive to detect numbers of $E$. coli $\mathrm{O} 157: \mathrm{H} 7$ as low as $10 \mathrm{cfu} \mathrm{g}^{-1}$ soil. Previous studies, reporting high PCR detection sensitivities in bovine faeces and meat, are limited through the use of freshly prepared cell cultures as inocula for spiking material (Hu et al. 1999; Sharma et al. 1999). However, in this study, the ability to detect low numbers of starved
Table 2 PCR detection sensitivity for nontoxigenic Escherichia coli O157:H7 strain 3704 in Glencorse soil

\begin{tabular}{cc}
\hline Starvation period $(\mathrm{d})$ & $\begin{array}{l}\text { PCR detection level } \\
\left(\mathrm{cfu} \mathrm{g}^{-1} \text { oven dry soil }\right)\end{array}$ \\
\hline 0 & 3 \\
1 & 3 \\
3 & 7 \\
7 & 2 \\
14 & 3 \\
21 & 3 \\
35 & 10 \\
\hline
\end{tabular}

Cells were starved in phosphate buffer for 1-35 d before inoculation into soil. Numbers presented represent initial cfu added to soil.

populations of E. coli $\mathrm{O} 157: \mathrm{H} 7$ was encouraging and increases confidence in the use of enrichment and PCRbased strategies for detection of this pathogen in environmental samples.

Cattle faeces are likely to be highly contaminated with other coliforms and serotypes of $E$. coli other than O157:H7. Environmental material was only inoculated with pure cultures of E. coli $\mathrm{O} 157: \mathrm{H} 7$, thus, possibly eliminating any competition effects during enrichment from other coliform bacteria that may have been introduced through cattle faeces. Previous studies, using the same enrichment media and PCR primers for detection of E. coli $\mathrm{O} 157: \mathrm{H} 7$ in spiked bovine faeces, reported sensitive pathogen detection down to initial inoculum values of $1 \mathrm{cfu} \mathrm{g}^{-1}$ material (Hu et al. 1999). These data suggest that enrichment conditions were appropriate, enabling growth of low numbers of target E. coli $\mathrm{O} 157: \mathrm{H} 7$ population despite the potential presence of other competing coliform bacteria that are likely to be high in cattle faeces. 


\section{Minimum enrichment time and PCR detection sensitivity}

Traditional culture based approaches for the detection of E. coli $\mathrm{O} 157: \mathrm{H} 7$, such as growth on SMAC agar, and further screening for production of Shiga-like toxin may take several days. Techniques which rapidly detect presence of pathogen are highly desirable, potentially accelerating diagnosis of disease in an individual, enabling earlier treatment. Rapid detection of the O157:H7 serotype in environmental samples may also be of benefit in screening private drinking water prior to human consumption, obtained from sources in proximity to agricultural land. In this study, the effects of length of enrichment time on PCR detection sensitivity of E. coli $\mathrm{O} 157: \mathrm{H} 7$ in Glencorse soil were investigated. Enrichment times as short as $6 \mathrm{~h}$ were required for simultaneous amplification of $\mathrm{H} 7$, intimin and $\mathrm{O} 157$ encoding genes when soil received an initial inoculum of $\geq 1 \cdot 13 \times 10^{4} \mathrm{cfu} \mathrm{g}^{-1}$ soil (Fig. 2). Faint bands, corresponding to the intimin and $\mathrm{O} 157$, but not the $\mathrm{H} 7$ gene products, could also be detected from soil that had been initially spiked with $1.13 \times 10^{2}$ and $1.13 \times 10^{3} \mathrm{cfu} \mathrm{g}^{-1}$ soil. According to the original study which developed this multiplex PCR assay and tested 19 different $E$. coli serotypes, the presence of the intimin amplicon on its own was sufficient to differentiate the O157:H7 serotype from other E. coli serotypes (Hu et al. 1999). The weakness or complete absence of the $\mathrm{H} 7$ product indicates inefficiency of amplification of this larger gene target during amplification. Despite this, increasing primary enrichment time to $8 \mathrm{~h}$ enabled detection of as few as $1.36 \times 10^{2} \mathrm{cfu} \mathrm{g}^{-1}$ soil through simultaneous amplification of the three gene targets (Fig. 3). PCR products

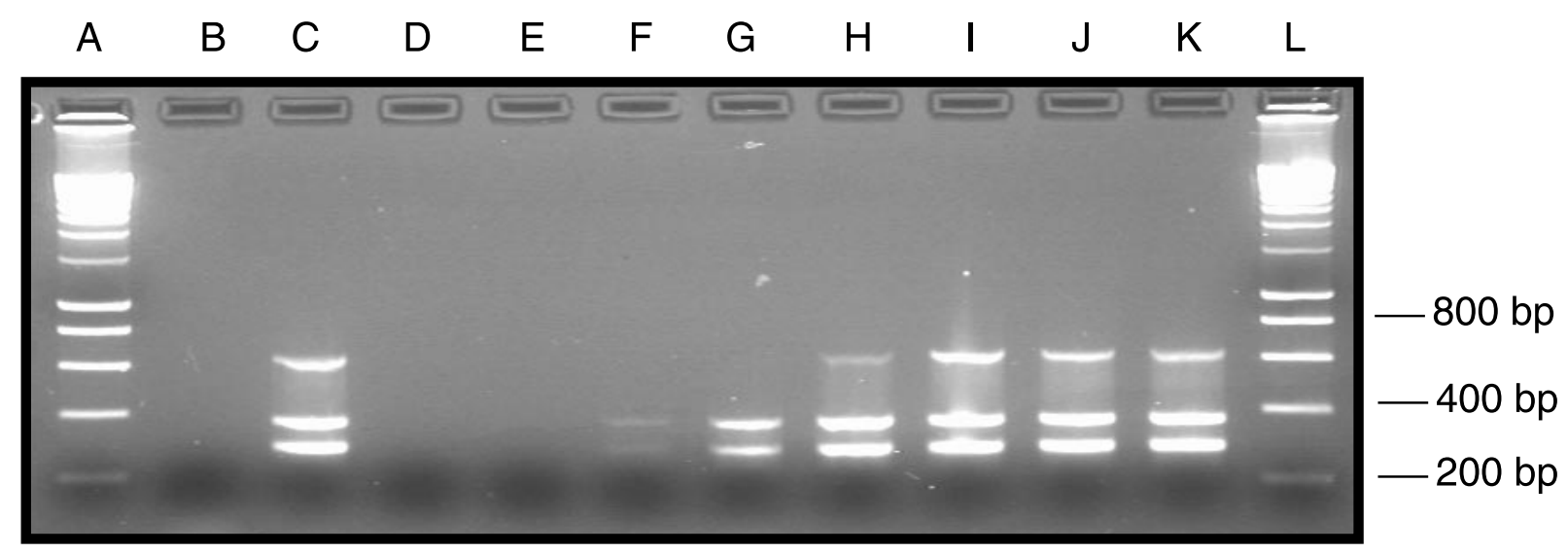

Fig. 2 Agarose gel electrophoresis demonstrating detection sensitivity of PCR for nontoxigenic E. coli O157:H7 strain 3704 after 6 h primary enrichment of Glencorse soil. Lanes: (A and L) HyperLadder (Bioline, UK, Ltd); (B) negative control (no template); (C) positive control pure culture DNA; (D) negative control, uninoculated soil; (E) $1 \cdot 13 \times 10^{1}$; (F) $1.13 \times 10^{2}$; (G) $1 \cdot 13 \times 10^{3}$; (H) $1 \cdot 13 \times 10^{4}$; (I) $1 \cdot 13 \times 10^{5}$; (J) $1 \cdot 13 \times 10^{6}$; and (K) $1 \cdot 13 \times 10^{7} \mathrm{cfu} \mathrm{g}^{-1}$ soil

\section{A}

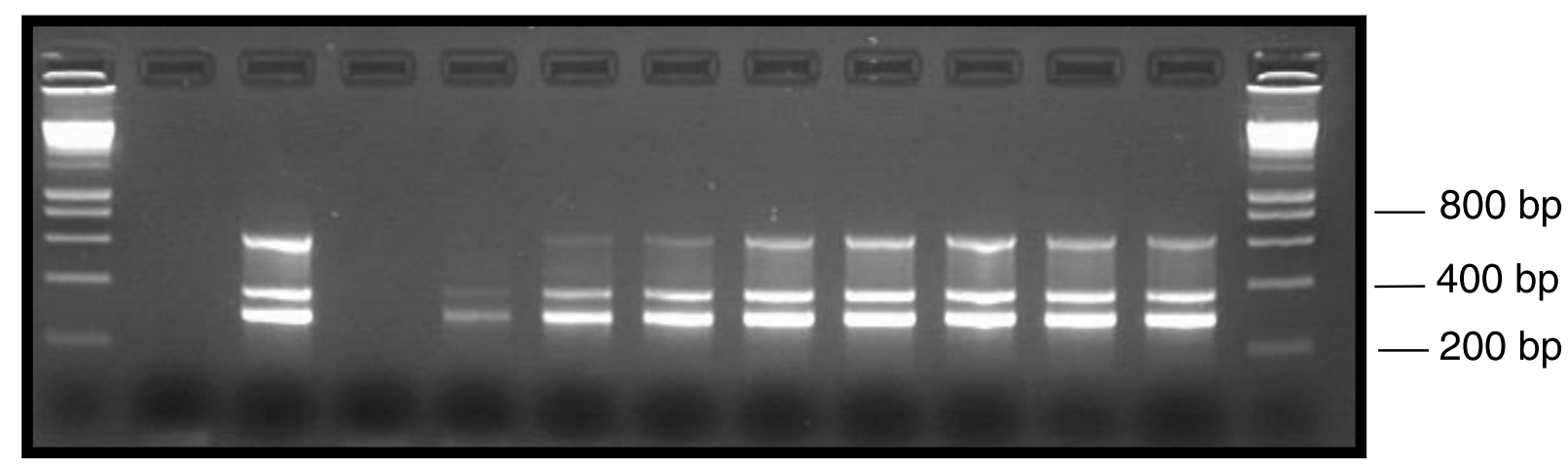

Fig. 3 Agarose gel electrophoresis demonstrating detection sensitivity of PCR for nontoxigenic E. coli O157:H7 strain 3704 after 8 h primary enrichment of Glencorse soil. Lanes: (A and M) HyperLadder (Bioline, UK, Ltd); (B) negative control (no template); (C) positive control pure culture DNA; (D) negative control, uninoculated soil; (E) $1.36 \times 10^{1}$; (F) $1.36 \times 10^{2}$; (G) $1.36 \times 10^{3} ;$ (H) $1.36 \times 10^{4}$; (I) $1.36 \times 10^{5}$; (J) $1.36 \times 10^{6}$; (K) $1.36 \times 10^{7}$ and (L) $1.36 \times 10^{8} \mathrm{cfu} \mathrm{g}^{-1}$ soil 
corresponding to $\mathrm{O} 157$ and intimin were also obtained from soil spiked with $1.36 \times 10^{1} \mathrm{cfu} \mathrm{g}^{-1}$ soil, although again the H7 product was absent. Use of an $8-\mathrm{h}$ primary soil enrichment, along with the multiplex PCR approach described here, offers the possibility of sensitive detection of $E$. coli $\mathrm{O} 157: \mathrm{H7}$ in soil within one working day. Pathogen detection time in soil and water could further be reduced by use of fluorogenic probes in PCR reactions (Bassler et al. 1995; Oberst et al. 1998; Sharma et al. 1999). This method avoids the need for agarose gel visualization of postamplification products due to the release of a fluorogenic reporter dye during DNA polymerization (Lee et al. 1993). Further, the application of rapid PCR thermal-cycling instrumentation coupled with the use of fluorogenic probes have resulted in PCR assay times as little as $20 \mathrm{~min}$ for detection of Bacillus spores (Belgrader et al. 2000). It may therefore be possible to combine these technologies for rapid detection of E. coli $\mathrm{O} 157: \mathrm{H} 7$.

\section{PCR detection of $E$. coli 0157:H7 population changes in Glencorse soil}

Glencorse soil was inoculated with a range of stationary phase $E$. coli $\mathrm{O} 157: \mathrm{H} 7$ cell numbers and sampled at various time points for $35 \mathrm{~d}$. Data indicated survival was dependent on initial cfu numbers added to soil (Table 3). With lower numbers of E. coli O157:H7 added, positive PCR amplicons indicated poorer survival than for soil receiving higher loadings of target bacteria. Data suggested a 10-fold decrease in cell concentration each week irrespective of initial cell concentration. With soil seeded with $3 \times 10^{5} \mathrm{cfu} \mathrm{g}^{-1}$ soil, positive PCR signals were observed throughout the $35 \mathrm{~d}$ incubation. However, for soil seeded with only $3 \mathrm{cfu} \mathrm{g}^{-1}$ soil, a positive PCR signal was only observed at $0 \mathrm{~d}$. These data suggest that a critical loading of $E$. coli $\mathrm{O} 157: \mathrm{H} 7$ is an important consideration relating to survival of this microorganism in soil. The limited studies which have reported long-term survival of $E$. coli $\mathrm{O} 157: \mathrm{H7}$ in soil have used relatively large inocula of this bacterium $\left(10^{6}-10^{7} \mathrm{cfu}^{-1}\right.$ soil $)$

Table 3 PCR detection of nontoxigenic Escherichia coli $\mathrm{O} 157: \mathrm{H} 7$ strain 3704 in Glencorse soil

\begin{tabular}{llllll}
\hline $\begin{array}{l}\text { Initial cell concentration } \\
\left(\mathrm{cfu} \mathrm{g}^{-1} \text { soil) }\right.\end{array}$ & $0 \mathrm{~d}$ & $7 \mathrm{~d}$ & $14 \mathrm{~d}$ & $21 \mathrm{~d}$ & $35 \mathrm{~d}$ \\
\hline $3 \times 10^{5}$ & + & + & + & + & + \\
$3 \times 10^{4}$ & + & + & + & + & - \\
$3 \times 10^{3}$ & + & + & + & + & - \\
$3 \times 10^{2}$ & + & + & + & - & - \\
$3 \times 10^{1}$ & + & + & - & - & - \\
$3 \times 10^{0}$ & + & - & - & - & - \\
\hline
\end{tabular}

Numbers presented represent initial cfu added to soil.
(Maule 1999; Fenlon et al. 2000; Mubiru et al. 2000). Such studies should therefore be regarded in the context of worst case risk for E. coli $\mathrm{O} 157: \mathrm{H} 7$ persistence. Research should also focus on examining survival in relation to smaller E. coli $\mathrm{O} 157: \mathrm{H} 7$ inocula in soil. This may be more appropriate, as numbers of $E$. coli $\mathrm{O} 157: \mathrm{H} 7$ present in cattle faeces are reported to be in the range of $10^{2}-10^{5} \mathrm{cfu} \mathrm{g}^{-1}$ faeces (Zhao et al. 1995; Shere et al. 1998).

\section{CONCLUSION}

In summary, a multiplex PCR-based approach in combination with an enrichment strategy, has been used for sensitive detection of $E$. coli $\mathrm{O} 157: \mathrm{H} 7$ in a variety of contrasting environmental materials. Speed and sensitivity make this assay potentially useful for screening rural drinking water supplies that are currently at high risk of $E$. coli $\mathrm{O} 157: \mathrm{H} 7$ contamination. Employing the conditions reported in this study, it is possible to obtain sensitive detection of $E$. coli O157:H7 in soil and water within one working day.

\section{ACKNOWLEDGEMENTS}

This work was supported by a grant (UAB/007/99) from the Scottish Executive Rural Affairs Department.

\section{REFERENCES}

Bassler, H.A., Flood, S.J., Livak, K.J., Marmaro, J., Knorr, R. and Batt, C.A. (1995) Use of fluorogenic probe in a PCR-based assay for the detection of Listeria monocytogenes. Applied and Environmental Microbiology 61, 3724-3728.

Belgrader, P., Okuzumi, M., Pourahmadi, F., Borkholder, D.A. and Northrup, M.A. (2000) A microfluidic cartridge to prepare spores for PCR analysis. Biosensors and Bioelectronics 14, 849-852.

Chapman, P.A. (2000) Sources of Escherichia coli $\mathrm{O} 157$ and experiences over the past 15 years in Sheffield, UK. Fournal of Applied Microbiology 88S, 51S-60S.

Chapman, P.A., Siddons, C.A., Cerdan Malo, A.T. and Harkin, M.A. (1997) A 1-year study of Escherichia coli O157 in cattle, sheep, pigs and poultry. Epidemiology and Infection 119, 245-250.

Chapman, P.A., Siddons, C.A., Zadik, P.M. and Jewes, L. (1991) An improved selective medium for the isolation of Escherichia coli O157. Fournal of Medical Microbiology 35, 107-110.

Fenlon, D.R. and Wilson, J. (2000) Growth of Escherichia coli $\mathrm{O} 157$ in poorly fermented laboratory silage: a possible environmental dimension in the epidemiology of Escherichia coli O157. Letters in Applied Microbiology 30, 118-121.

Fenlon, D.R., Ogden, I.D., Vinten, A. and Svoboda, I. (2000) The fate of Escherichia coli $\mathrm{O} 157$ in cattle slurry after application to land. Journal of Applied Microbiology 88S, 149S-156S.

Fratamico, P.M., Bagi, L.K. and Pepe, T. (2000) A multiplex polymerase chain reaction assay for rapid detection and identification of Escherichia coli O157:H7 in foods and bovine feces. Fournal of Food Protection 63, 1032-1037. 
Fukushima, H., Hoshina, K. and Gomyoda, M. (1999) Long-term survival of Shiga toxin-producing Escherichia coli O26, O111, and O157 in bovine feces. Applied and Environmental Microbiology 65, 5177-5181.

Gagliardi, J.V. and Karns, J.S. (2000) Leaching of Escherichia coli O157:H7 in diverse soils under various agricultural management practices. Applied and Environmental Microbiology 66, 877-883.

Hara-Kudo, Y., Miyahara, M. and Kumagai, S. (2000) Loss of O157 O antigenicity of verotoxin-producing Escherichia coli $\mathrm{O} 157: \mathrm{H} 7$ surviving under starvation conditions. Applied and Environmental Microbiology 66, 5540-5543.

Hu, Y., Zhang, Q. and Meitzler, J.C. (1999) Rapid and sensitive detection of Escherichia coli $\mathrm{O} 157: \mathrm{H} 7$ in bovine faeces by a multiplex PCR. Fournal of Applied Microbiology 87, 867-876.

Jones, D.L. (1999) Potential health risks associated with the persistence of Escherichia coli $\mathrm{O} 157$ in agricultural environments. Soil Use and Management 15, 76-83.

Lee, L.G., Connell, C.R. and Bloch, W. (1993) Allelic discrimination by nick-translation PCR with fluorogenic probes. Nucleic Acids Research 21, 3761-3766.

Maule, A. (1999) Environmental aspects of E. coli O157. International Food Hygiene 9, 21-23.

Meng, J., Zhao, S., Doyle, M.P., Mitchell, S.E. and Kresovich, S. (1997) A multiplex PCR for identifying Shiga-like toxin-producing Escherichia coli O157:H7. Letters in Applied Microbiology 24, 172-176.

Mubiru, D.N., Coyne, M.S. and Grove, J.H. (2000) Mortality of Escherichia coli $\mathrm{O} 157: \mathrm{H} 7$ in two soils with different physical and chemical properties. Fournal of Environmental Quality 29, 1821-1825.

Nagano, I., Kunishima, M., Itoh, Y., Wu, Z. and Takahashi, Y. (1998) Detection of verotoxin-producing Escherichia coli O157:H7 by multiplex polymerase chain reaction. Microbiology and Immunity 42, 371-376.

Oberst, R.D., Hays, M.P., Bohra, L.K., Phebus, R.K., Yamashiro, C.T., Paszko-Kolva, C., Flood, S.J.A., Sargeant, J.M. and Gillespie, J.R. (1998) PCR-based DNA amplification and presumptive detection of Escherichia coli $\mathrm{O} 157: \mathrm{H7}$ with an internal fluorogenic probe and the $5^{\prime}$ nuclease assay. Applied and Environmental Microbiology 64, 3389-3396.
Rocelle, M., Clavero, S. and Beuchat, L.R. (1995) Suitability of selective plating media for recovering heat- or freeze-stressed Escherichia coli $\mathrm{O} 157: \mathrm{H} 7$ from tryptic soy broth and ground beef. Applied and Environmental Microbiology 61, 3268-3273.

Scottish Environment Protection Agency (1998) Strategic Reviem of Organic Waste Spread on Land. Technical Report.

Sharma, V.K., Dean-Nystrom, E.A. and Casey, T.A. (1999) Semiautomated fluorogenic PCR assays (TaqMan) for rapid detection of Escherichia coli $\mathrm{O} 157: \mathrm{H} 7$ and other Shiga toxigenic E. coli. Molecular and Cellular Probes 13, 291-302.

Shere, J.A., Bartlett, K.J. and Kaspar, C.W. (1998) Longitudinal study of Escherichia coli $\mathrm{O} 157: \mathrm{H} 7$ dissemination on four dairy farms in Wisconsin. Applied and Environmental Microbiology 64, 1390-1399.

Taormina, P.J., Rocelle, M., Clavero, S. and Beuchat, L.R. (1998) Comparison of selective agar media and enrichment broths for recovering heat-stressed Escherichia coli O157:H7 from ground beef. Food Microbiology 15, 631-638.

Tebbe, C.C. and Vahjen, W. (1993) Interference of humic acids and DNA extracted directly from soil in detection and transformation of recombinant DNA from bacteria and a yeast. Applied and Environmental Microbiology 59, 2657-2665.

Wang, G. and Doyle, M.P. (1998) Survival of enterohemorrhagic Escherichia coli $\mathrm{O} 157: \mathrm{H} 7$ in water. Journal of Food Protection 61, 662-667.

Willshaw, G.A., Thirwell, J., Jones, A.P., Parry, S., Salmon, R.L. and Hickey, M. (1994) Vero cytotoxin-producing Escherichia coli $\mathrm{O} 157$ in beefburgers linked to an outbreak of diarrhoea, haemorrhagic colitis and haemolytic uraemic syndrome in Britain. Letters in Applied Microbiology 19, 304-307.

Wright, D.J., Chapman, P.A. and Siddons, C.A. (1994) Immunomagnetic separation as a sensitive method for isolating Escherichia coli $\mathrm{O} 157$ from food samples. Epidemiology and Infection 113, 31-39.

Zadik, P.M., Chapman, P.A. and Siddons, C.A. (1993) Use of tellurite for the selection of verocytotoxigenic Escherichia coli O157. Fournal of Medical Microbiology 39, 155-158.

Zhao, T., Doyle, M.P., Shere, J. and Garber, L. (1995) Prevalence of enterohemorrhagic Escherichia coli $\mathrm{O} 157: \mathrm{H} 7$ in a survey of dairy herds. Applied and Environmental Microbiology 61, 1290-1293. 